\title{
The Impacts of Political Corruption on Democratic Consolidation and the Electoral Process in Nigeria
}

Joseph C. Ebegbulem, PhD

Department of Political Sciences

University of Calabar, Nigeria

\section{Abstract}

Since 1999, Nigeria has witnessed an uninterrupted democratic experiment with many challenges. With the installation of multi-party democracy in Nigeria, the era of military authoritarian regimes were over as Nigerians were looking forward to a free society characterized by social justice, economic growth and free, fair and credible electoral process. But today, democracy sits on the horn of a dilemma in Nigeria due to massive political corruption by the leaders. Free and fair election which is one of the features of true democracy has eluded Nigeria since the advent of the country's nascent democratic dispensation. The behavior of the political leaders has cast doubt on any consolidation of democracy in Nigeria. This paper gives a comprehensive definition of political corruption and democratic consolidation, and highlights the nature of political corruption in Nigeria. The paper also examines the impact of corruption on the consolidation of democracy under the prevailing socio-economic challenges in Nigeria. Finally, the paper concludes with the advice that for there to be democratic consolidation, there must be massive investment in the provision of the basic needs of the Nigerian people.

Keywords: political corruption; democratic consolidation; godfatherism; ethnicism; democracy.

\section{Introduction}

As a Conceptual Clarification

\section{Political Corruption}

Political corruption has been given broad and varied definitions by scholars from different perspectives. According to Obayelu (2007), political corruption is the exploitation of public position, resources and power for private gain. For Sen (1999: 275), political corruption is the "violation of established rules for personal gains and profit".

Defining political corruption from a sociological point of view, Atlas (1968) sees it as a symptom of dysfunctionality of the relationship between the state and the people, characterized by bribery, extortion and nepotism. Looking at it from a political point of view, Aiyede (2006: 38) defines political corruption as "the abuse or misuse of public or governmental power for illegitimate private advantage". Corroborating Aiyede's 
definition, Lipset and Lenz (2000) posit that political corruption is an effort to secure wealth and power through illegal means for private benefit at public expense. Such an abuse of power may not necessarily be for one's private benefit. It may be for the benefit of one's political party, social class, tribe or family.

Igwe (2010: 195) notes that:

Most definitions however, describe its scope to mean any organized, interdependent system in which part of the system is either not performing its duties as ethically expected or is performing them in an improper way, to the detriment of the system's original purpose. In other words, corruption covers a broad spectrum of activities ranging from fraud (theft through misrepresentation, embezzlement, misappropriation of corporate or public funds) to bribery (payments made in order to gain an advantage or to avoid a disadvantage).

What constitutes corruption varies from one country to another. In countries with strong interest group politics, practices that could easily constitute corruption elsewhere are sometimes sanctified as official group preferences. Thus, there is an attempt to shift the definition from the purely legalistic arena into the realm of ethics (Aiyede, 2006).

Corruption affects all polities in a negative way. The effects are more acute in emerging economies of the third world countries. There is no doubt that positive change and economic growth cannot thrive in an endemically corrupt society.

\section{Democratic Consolidation}

The concept of democratic consolidation has been defined by scholars based on their understanding. They have come up with different definitions to describe the concept. Linz (1985) believes and argues that democracy is consolidated when none of the major political actors, parties or organized interest, forces or institutions consider that there is any alternative to the democratic process to gain power and no political institutions or groups has a claim to veto the actions of democratically elected decision makers. According to Diamond (1999), democratic consolidation is "the process of achieving broad and deep legitimation such that all significant political actors believe that popular rule is better for the society than any other realistic alternative they can imagine" (Diamond, 1999 cited in Kwasau, 2013: 182).

Some scholars view democratic consolidation as a regime maintenance which regards key political institutions as the only legitimate framework for political contestation and adherence to the democratic rules of the game. Democratic consolidation can only manifest under enhanced economic development, advanced and developed political culture, stable party system and improved and independent electoral process. The building of a consolidated democracy involves an affirmation and strengthening 
of certain institutions, such as the electoral system, vibrant political parties, judicial independence, respect for human rights and rule of law. Real democratic consolidation requires a demonstrable relationship between political accountability and quality governance.

Akinsanya, arguing within the thematic view of democratic consolidation and the necessity of the electoral process, asserts that "a consolidated democracy is measured by the extent to which a country has regular free and fair elections, genuine contestation over selection...." (Akinsaya, 2006: 44). He states further that democratic consolidation requires stability. He believes that a high degree of stability brings about accountability, transparency, responsiveness and competitiveness.

\section{Political Corruption And Consolidation Of Democracy}

Corruption has posed a serious challenge to the consolidation of democracy in any country where it thrives. It undermines democracy and good governance by flouting or even subverting formal processes. "Corruption in elections and in legislative bodies reduce accountability and distorts representation in policy making; corruption in the judiciary compromises the rule of law; and corruption in public administration results in the unfair and inefficient provision of services" (Aiyede, 2006: 39). Aiyede states further that, "more generally, corruption erodes the institutional capacity of government as procedures are disregarded, resources are siphoned off, and public offices are bought and sold. Thus corruption undermines the legitimacy of government and democratic values of trust and tolerance.

Nigeria's democratic consolidation since the inception of uninterrupted democracy in 1999 has been a problematic endeavor because elections and the electoral process have been bereft of democratic ideals. According to Ibeanu (2007: 3):

The electoral process as currently constituted in Nigeria is psychologically alienating from the vast majority of the people who are largely outsiders and are only periodically inserted in the process when they cast votes. At the same time, this alienation is underscored by the fact that even when these vote casters have completed the ritual of voting, the outcome bears little semblance to what they chose in their ballots.

Ibeanu's view is highlighted by Aiyede (2006) who observed that in Nigeria, corruption has made election result to have very little or nothing to do with the performance in office of politicians. He argues further that because performance is not a critical factor in electoral outcome, the incentive to perform is very weak. Since corruption is effective in achieving electoral victory, the incentive to resort to corrupt practices is very high. The main decisive factors in the outcome of elections in Nigeria have been ethnicity, intimidation and massive vote buying and rigging. 
Political parties in Nigeria today do not articulate any concrete programme during campaigns on how to take the country out of the woods. They rather spend billions of naira on outright bribery and vote buying,

The most annoying part of political corruption is the fact that even institutions that are established to enforce the rules and check the excesses of politicians and political parties are themselves implicated in political corruption. There have been evidences during the past elections that officials of the Independent National Electoral Commission (INEC) have colluded, sometimes with monetary inducement, to perpetrate violence, rigging and doctoring of election results. The same applies to the police, the State Security Services (SSS) and the National Intelligence Agency (NIA). Also worrisome is the real capacity of individuals to determine electoral outcomes by corrupt means, judging by the role of godfathers in Nigeria's political process (Aiyede, 2006).

Political corruption has affected the cognitive perception of Nigerians since the current democratic experiment began in 1999. First there is doubt about the ability of the Nigerian state to organize a free, fair and credible election; second there is this perception that political appointments are one sure way to wealth and elevation of social status; and third, there is also the perception that the political office holders cannot be responsible and accountable to the citizens. The impact of this on democratic consolidation in Nigeria is clear.

Consequently, as the philosophical basis and fundamental ethos of democracy are being swept under the carpet, the Nigerian electorate expectedly lost faith not only in the electoral process, but fundamentally on the government which the fraudulent process produced (Ogundiya, 2006). With all these, the legitimacy of democracy as the best form of government has been seriously eroded. Corruption has reached a level in Nigeria such that an average Nigerian citizen believes that there is an inextricable link between corruption and democracy.

Under corrupt democratic government, good governance predicated on the rule of law, due process, accountability, transparency in the management of the state's affairs is precariously compromised.

\section{Challenges To Democratic Consolidation In Nigeria}

The electoral process in Nigeria has been bedeviled with major challenges which has dealt a huge blow to democratic consolidation in Nigeria. Election rigging is one of such challenges. Elections conducted by the Independent National Electoral Commission (INEC), the country's electoral body since 1999, have not met the expectations of Nigerians as a result of various forms of electoral malpractices. This has made elections in Nigeria far from being free, fair and credible. Election rigging has not only marred democratic consolidation in Nigeria, but has also disenfranchised many Nigerians. 
It has promoted the imposition of unqualified and corrupt individuals on Nigerians who have no regard and respect for the principle of democracy.

Inadequate security is also one of the major challenges to democratic consolidation in Nigeria. This gives impetus to Dauda and Avidime's submission that the security situation in Nigeria is a major challenge to the consolidation of democracy in Nigeria. They note that "the tense security situation in all parts of the country makes nonsense of whatever efforts have been made to justify the sustenance of our democratic experiment since the environment is unconducive for foreign investments and endangered by bad governance and political instability (Dauda and Avidime, 2007: 18). According to the duo, the problem of youth unemployment cannot be divorced from the current security challenges in Nigeria which poses a threat to democratic consolidation and national security.

Ethnicism is another obstacle to democratic consolidation in Nigeria. The problem of ethnicism in Nigeria's political process cannot be divorced from socio-political instability in the country. Frequent ethnic induced turbulences in Nigeria and the clamour for the presidency by the various ethnic nationalities in the country indicate that the Nigerian society is still balkanized by tribal sentiments (Victor, 2002). The various ethnic nationalities in Nigeria encourage and promote ethnic interest, thereby making the creation of a common identity problematic. This poses a threat to democratic consolidation in Nigeria.

Poverty also makes the consolidation of democracy a herculean task in Nigeria. Poverty is a consequence of unemployment which is part of the Nigerian society. Any society that is characterized by poverty cannot develop, and such a society is always unstable. Poverty and unemployment have posed serious hindrance to the consolidation of democracy in Nigeria. It is estimated that over eighty percent of Nigerians are poor, and this level of poverty accounts for part of the security challenges in Nigeria today, because the unemployed and poor youths carry arms against the state and its citizens. As a result of poverty, many Nigerians are easily brainwashed during elections, as they become victims of various forms of inducements and gratification. This is a barrier to Nigeria's quest for democratic consolidation.

Corruption is another major impediment to the consolidation of democracy in Nigeria. The Nigerian state is synonymous with corruption. Events in Nigeria since the country's democratic experiment in 1999 have shown that corruption is a clog in the wheel of Nigeria's democratic project. It has devastated and eroded the fundamental values and principles of democracy in Nigeria. Kwasau (2013: 186) observes that:

Corruption has reached a high crescendo such that an average Nigerian now possibly associates democracy with it. The consequences of political corruption are potently manifest cyclical crisis of legitimacy, fragile party structure, institutional decay, chronic economic problem and unemployment, and above all general democratic volatility. 
Godfatherism in Nigerian politics which negates all tenets of democracy also poses a threat to the consolidation of democracy in Nigeria. Godfatherism prevents the selection of competent and qualified candidates for elective positions. The so-called Godfathers achieve their goals with money and where this method proves unsuccessful, they unleash violence both as deterrence and punishment. Elections can never be free and fair, and governance cannot be accountable and transparent under the politics of godfatherism. In Nigeria, since the enthronement of democracy in 1999, the politics of godfatherism has created doubts about the legitimacy of the electoral process and those produced by the same electoral process. Godfatherism is one of the biggest dangers to democratic consolidation as it promotes the exclusion and denial of legitimate entitlements of the electorate.

Gambo sees the activities of godfathers as inimical to the tenets of democracy. According to him, under the politics of godfatherism, "there is total absence of culture of accountability, and this engates one of the critical attributes of democracy which is a responsible and accountable government. Good governance predicated on rule of law, due process, accountability and transparency in the management of public space is precariously compromised" (Gambo, 2006: 99). Ayoade also notes that:

Godfatherism has created more problems than enough. It has created doubts about the legitimacy of the electoral process and the elected. It therefore creates an environment that delinks people from the state. The opposition tends to refuse to obey what conscience forbids. They therefore react by becoming apathetic or, at the other extreme, violent. Those that remain apathetic do so only because they do not hold strong political views, while those who turn violent cannot accommodate the blatant disregard of rules (Ayoade, 2006: 87).

\section{Conclusion}

There is no doubt that what pervades in the Nigerian state is insecurity, poverty, unemployment, inadequate health care system and total economic depression. These are the consequence of political corruption which has endangered our democratic consolidation. The near total collapse of Nigeria's social infrastructure and other institutions is traceable to massive political corruption exhibited by the political class.

Corruption has greatly eroded the fundamental values of democracy and the essential principle that government should be representative and accountable to the people. When political leaders are perceived to be pursuing their personal interests excessively, the people become disenchanted, questioning the legitimacy of the leaders and the state, and even the legitimacy of the process and the system that produced them. Political corruption has greatly eroded the basis of the authority of the state, and has challenged the legitimacy of democracy as the best form of government. 
Democratic consolidation may be difficult to achieve in Nigeria as long as political corruption remains endemic and unchecked.

For there to be meaningful democratic consolidation in Nigeria in the absence of corruption, there must be massive investment in the provision of the basic needs of the Nigerian people. These include the need for personal safety; employment opportunities; development of infrastructural projects, healthcare, etc. Poverty alleviation should thus be seen as a democratic necessity rather than a political programme designed to win votes. There is an evident truth that democracy cannot be consolidated in an environment of abject poverty, insecurity, hunger and injustice which are the products of political corruption.

\section{Bibliography}

1. Aiyede, R. E. (2006). "The Role of INEC, ICPC and EFCC in Combating Political Corruption" in Money, Politics and Corruption. Abuja: Garkida Press Limited

2. Atlas, S. H. (1986). The Sociology of Corruption: The Nature, Function, Causes and Prevention of Corruption. Singapore: Hoong Falt Press

3. Ayoade, J. (2006). "Godfather Politics in Nigeria", in Money, Politics and Corruption. Abuja: Garkida Press Limited

4. Cani, E. M. H. (2011). The status of the Civil Servant \& Rules of Ethics in Public Admin efficacy in preserving the integrity of civil servants and preventing corruption. Academicus International Scientific Journal, 2(04), 81-91.

5. Dauda, O. and Avidime, S. (2007). Towards a Sustainable Democratic Governance in Nigeria's Fourth Republic. Millennium Journal of International Studies. Owerri: Chengho Limited

6. Diamond, L. (1999). "Globalisation of Democracy: Trends, Types, Causes and Prospects". In Okon, E. U. ed. Civil Society and the Consolidation of Democracy in Nigeria. Calabar: CATS Publishers

7. Gambo, A. (2006). "Godfatherism and Electoral Politics in Nigeria", in Money, Politics and Corruption. Abuja: Garkida Press Limited

8. Haxhiraj, A. (2013). Judicial Enforcement of Economic, Social and Cultural Right. Academicus International Scientific Journal, 4(08), 221-230.

9. Igwe, S. C. (2010). How Africa Underdeveloped Africa. Port Harcourt: Professional Printers and Publishers

10. Iovan, M. (2018). The Principles of the Equity and the Rightful Person's Personality in the Democratic Context. Academicus International Scientific Journal, 9(18), 63-72. 
11. Kwasau, N. A. (2013). The Challenges of Democratic Consolidation in Nigeria's Fourth Republic. European Scientific Journal, Vol. 9, No. 8

12. Linz, J. (1985). Democracy, Presidential or Parliamentary: Does it make a difference. World Peace Foundation

13. Lipset, S. M. and Lenz, G. S. (2000). "Corruption, Culture and Markets. In, Lawrence E. and Huntington, S. eds. Culture Matters. New York: Basic Books

14. Ogundiya, I. S. (2009). Political Corruption in Nigeria: Theoretical Perspectives and some Explanations. The Anthropologist, Vol. 11, No. 4

15. Popova-Koskarova, R. (2015). Developing Interethnic and Intercultural Competencies. Academicus International Scientific Journal, 6(12), 260-269.

16. Sen, A. (1999). Development as Freedom. New York: Anchor Books

17. Tanzi, V. (1998). Corruption Around the World: Causes, Consequences, Scope and Curses. IMF Working Paper No. 63 